\title{
Seasonal bacteriological analysis of Barak River, Assam, India
}

\author{
Bibhas Rajkumar · G. D. Sharma
}

Received: 17 September 2012/ Accepted: 1 July 2013/Published online: 14 July 2013

(C) The Author(s) 2013. This article is published with open access at Springerlink.com

\begin{abstract}
The present study was aimed at estimating the seasonal variation of human pathogenic bacteria in different sites of the Barak River. Water samples were collected in different seasons of the year from four sites of the river for physico-chemical and bacteriological analysis. Total alkalinity showed a rising trend during summer and winter seasons. In contrast, the values declined during monsoon season. $\mathrm{pH}$ values, however, showed a narrow range of fluctuations over the seasons as well as among the study sites. In the site Panchgram higher value of dissolved oxygen was observed during monsoon season which gradually declined attaining minimum during winter season. During monsoon season, the free carbon dioxide $\left(\mathrm{FCO}_{2}\right)$ value was found to be high whereas lower values of $\mathrm{FCO}_{2}$ were observed during summer and winter seasons. All samples were found to have total viable count (TVC) higher than those prescribed by Bureau of Indian Standards (ISI, 1991). The TVC was higher in monsoon season as compared to summer and winter. The total coliform count was also relatively higher in monsoon season than summer and winter in all the sites. Pseudomonas spp. was recorded from all sites in all seasons which were higher in monsoon in comparison to other seasons. The highest value of MPN was found in the site Panchgram and Annapurnaghat $(1,600 \mathrm{MPN} / 100 \mathrm{ml})$ during monsoon season and lowest was found in the site Katakhal (110 MPN/100 ml) during winter season.
\end{abstract}

Keywords Barak River - Faecal coliforms . Pollution indicator

B. Rajkumar $(\bowtie) \cdot$ G. D. Sharma

Department of Life Science and Bioinformatics, Assam University, Silchar 788011, Assam, India e-mail: bibhasrajkumar@gmail.com

\section{Introduction}

Water the most important resource of nature is increasingly becoming a scare resource. Rivers are playing an important role as major water resource. Unfortunately, rivers are being polluted by indiscriminate disposal of sewage and industrial waste, which affects its physico-chemical properties and microbiological quality (Koshy and Nayar 1999). In the recent past, expanding human population, industrialisation, intensive agricultural practices and discharge of massive amount of wastewater into the river have resulted in deterioration in water quality. Water is playing an important role in the transmission of human disease. Faecal matter in water contains human enteric bacteria and therefore faecal contamination is one of the most important criteria for water quality assessment (Scott et al. 2003). Coliforms are the major microbial indicator of water quality monitoring. Therefore, bacteriological assessment, particularly for total coliforms or faecal coliforms, is routinely carried out to ascertain the quality and potability of water. The determination of total coliform and total faecal coliform count is the most widely used bacteriological methods for assessment of the quality of drinking water. The presence of such bacteria can be taken as an indicator of faecal contamination of the water and thus, to determine why such contamination is present, how serious it is and what steps can be taken to eliminate is important.

The World Health Organisation (1996) provided guidelines for drinking water quality and recommended that no faecal coliform should be found in drinking water. Presence of faecal coliforms as E. coli serves as an indicator for the possible presence of other disease causing pathogens. Faecal coliforms are selected members of the coliform group of bacteria which are able to ferment lactose at $37{ }^{\circ} \mathrm{C}$ and fairly specific for the faeces of warm blooded animals. The bacteriological parameters of 
different river systems have been studied by various groups (Badra et al. 2003; Arvanitidou et al. 2005). The bacteriological examination of water has a special significance in pollution studies, as it is a direct measurement of deleterious effect of pollution on human health. The present study focuses on the culturable bacterial diversity of the Barak River system for its pollution status. This study assesses seasonal water quality of Barak River water with the uses of bacteriological variables.

\section{Materials and methods}

\section{Study area}

The Barak River is one of the major river system in northeast India. It is located in the southern part of Assam, India. Geographically the site is situated at longitude of $24^{\circ} 41^{\prime \prime}$ $29.9^{\prime \prime} \mathrm{N}$ and latitude at $92^{\circ} 45^{\prime \prime} 25.9^{\prime \prime} \mathrm{E}$ with an altitude of about $36 \mathrm{~m}$ above mean sea level. The Barak River originates from the Nagaland-Manipur states of India passes through Assam and merges with Brahmaputra in Bangladesh before emerging into the Bay of Bengal. The main tributaries of the Barak River in India are the Jiri, the Dhaleswari, the Singla, the Longai, the Madhura, the Sonai, the Rukni and the Katakhal.

\section{Weather condition}

Generally, the daily temperature in the Barak Valley is about $15{ }^{\circ} \mathrm{C}$ in January. From April it rises and in July, the mean temperature ranges from 25 to $27^{\circ} \mathrm{C}$. During October, the daily mean temperature is above $25^{\circ} \mathrm{C}$. The subtropical climate of this valley is characterised by high rainfall and high humidity and can be characterised by three dominant seasons viz; winter (November-February), summer (March-May) and monsoon (June-October).

\section{Sampling sites and sampling methods}

Water samples were collected from four different sites of the Barak River, viz; (a) Panchgram (near Hindustan Paper Corporation). (b) Katakhal (upstream) - tributary merging with Barak River. (c) Annapurnaghat (upstream) - municipal waste water mixing point. (d) Sadarghat (upstream) water intake point of PHE. Samples were collected during the winter, summer and monsoon seasons (2010-2011). One litre of water from each location was collected into pre-sterilised bottles. All samples were collected with precautions required for microbiological analysis and transmitted to the laboratory for microbial analysis.

\section{Physico-chemical analysis}

The water samples from different sites and seasons were analysed for $\mathrm{pH}$, dissolved oxygen, alkalinity and $\mathrm{FCO}_{2}$. Dissolved oxygen was determined by modified Winkler's azide method, $\mathrm{pH}$ by digital $\mathrm{pH}$ meter, alkalinity and $\mathrm{FCO}_{2}$ were measured by titrimetric method. All the physicochemical parameters were analysed following the standard protocols of APHA (1998).

\section{Bacteriological analysis}

For the isolation and enumeration of bacteria, each water sample was serially diluted in sterile distilled water and plated on nutrient agar and different selective media. The bacterial populations in different samples were estimated by the spread plating method on different media using $1 \mathrm{ml}$ of suitable dilutions. All media plates were incubated at $37^{\circ} \mathrm{C}$ for $24-48 \mathrm{~h}$ and final counts of colonies were noted. The water quality was determined by the standard most probable number (MPN) method. Fermentation tubes were inoculated with 10, 1 and $0.1 \mathrm{ml}$ aliquots of water sample (APHA 1998). The tubes were incubated at $37{ }^{\circ} \mathrm{C}$ for $24 \mathrm{~h}$. Positive tubes producing acid and gas were used in estimating the presumptive MPN/ $100 \mathrm{ml}$. Confirmed test was carried out by transferring a loopful of broth from a positive tube into Brilliant green lactose bile (BGLB) broth, followed by incubation at $37{ }^{\circ} \mathrm{C}$ for 24-48 h. The tubes were observed for gas formation. Completed test was performed by plating a loopful of broth from a positive BGLB tube on to an Eosine Methylene Blue (EMB) Agar plate. The plates were incubated at $37^{\circ} \mathrm{C}$ for $24-48 \mathrm{~h}$ and observed for dark red colonies with metallic green sheen. Final faecal coliform or $E$. coli count as MPN/100 ml was calculated based on the completed test. All the culture media were obtained from HiMedia Pvt. Ltd., Bombay, India (Table 1).

Statistical analysis

All experiments were performed in triplicates and two-way analysis of variance (ANOVA) was performed according to the standard method (Steel and Torrie 1992).

Table 1 Detail of specific culture media used for quantitative bacterial analysis

\begin{tabular}{lll}
\hline Media name & Specificity & Manufacturer \\
\hline BGLB & Enterobacteriaceae & HiMedia, Mumbai, India \\
EMB & E.coli and total coliform & HiMedia, Mumbai, India \\
XLD & Agar Salmonella sp., & HiMedia, Mumbai, India \\
& $\quad$ Shigella sp. & \\
King's B Agar & Pseudomonas spp. & HiMedia, Mumbai, India \\
Nutrient Agar & Total viable count & HiMedia, Mumbai, India \\
\hline
\end{tabular}




\section{Results and discussion}

The physico-chemical analysis carried out from different sites during different seasons has been presented in Table 2. The data show the average of three samples per season. Total alkalinity showed a rising trend during summer and winter season. In contrast, the values declined during monsoon season. Measurement of hydrogen ion concentration enables us to understand the chemical conditions prevalent in aquatic ecosystem. $\mathrm{pH}$ values, however, showed a narrow range of fluctuations over the seasons as well as among the study sites. In the site Panchgram higher values of dissolved oxygen (DO) were observed during the monsoon season which gradually declined attaining minimum during winter season. More or less similar trend was also observed in the other three sites. During the monsoon season, the free carbon dioxide $\left(\mathrm{FCO}_{2}\right)$ value was found to be high whereas lower values of $\mathrm{FCO}_{2}$ were observed during the summer and winter seasons. Microbial analyses are presented in Table 3. All samples were found to have total viable counts (TVC) higher than those prescribed by Bureau of Indian Standards (ISI 1991). The TVC was higher in the monsoon season as compared to summer and winter. TVC for water samples were the highest during monsoon and the least during the winter season. In the Barak River the TVC was in the range of 22-42 $\left(\times 10^{3}\right) \mathrm{ml}^{-1}, 12-34\left(\times 10^{3}\right) \mathrm{ml}^{-1}$ and 10-19 $\left(\times 10^{3}\right) \mathrm{ml}^{-1}$ during monsoon, summer and winter season, respectively. Total viable count was found highest in the site Panchgram. The overall TVC was higher during monsoon than other seasons. The total coliform (TC) count was also relatively higher in the monsoon season than summer and winter in all the sites. The total coliform was in the range of 13-49 $\left(\times 10^{3}\right) \mathrm{ml}^{-1}, 11-42\left(\times 10^{3}\right) \mathrm{ml}^{-1}$ and $8-26\left(\times 10^{3}\right) \mathrm{ml}^{-1}$ during monsoon, summer and winter season, respectively. The range of SA/SH observed in the Barak River were 11-63 $\left(\times 10^{3}\right) \mathrm{ml}^{-1}, 3-45\left(\times 10^{3}\right)$ $\mathrm{ml}^{-1}$ and 5-49 $\left(\times 10^{3}\right) \mathrm{ml}^{-1}$ in monsoon, summer and winter, respectively. Pseudomonas spp. were recorded from all sites in all seasons, but were higher in monsoon in comparison to other seasons. The Pseudomonas spp. were in the range of $8-16\left(\times 10^{3}\right) \mathrm{ml}^{-1}, 5-14\left(\times 10^{3}\right) \mathrm{ml}^{-1}$ and 3-11 $\left(\times 10^{3}\right) \mathrm{ml}^{-1}$ in monsoon, summer and winter, respectively. The faecal coliform group of bacteria has been the principal indicator of the suitability of water for domestic use. In the present study, the total faecal coliform count in the Barak River was in the range of 910-1,600 (MPN/100 ml), 210-350 (MPN/100 ml) and 110-280 (MPN/100 ml) in monsoon, summer and winter season, respectively. The highest value of MPN was found in the site Panchgram and Annapurnaghat (1,600 MPN/100 ml) during monsoon season and lowest in the site Katakhal (110 MPN/100 ml) during winter season.

Populations of aquatic microbiota are influenced by many environmental parameters. High level of pollution indicator bacteria in river water is also a common problem in urban and rural areas that often leads to outbreaks of serious water-borne diseases like cholera, dysentery, etc. The bacteriological analysis revealed that the entire sample collected from four different sites of the Barak River was contaminated with coliform, faecal coliform and some other pathogenic bacteria. In the present study, all sites were found to possess high total viable counts. Hindustan Paper Corporation near Panchgram has direct connection with the river water of the Barak River and they are directly discharging the industrial effluents to the river. The TVC values suggest that they are discharging the industrial effluent to the river water. This practice should be avoided. The total viable count in the site Panchgram near Hindustan Paper Corporation was higher than other three sites which may be attributed to pollution by industrial wastes. The statistical analysis of different sites and seasons also showed significant variations (ANOVA, $P<0.05$ ). The population of total faecal coliform (TFC) from all the sites showed more or less similar values but marked differences were observed in different seasons. Therefore, significant variations were noted between different seasons (ANOVA, $P<0.01)$. In the present study, the Panchgram site showed

Table 2 Physico-chemical analysis of the water samples from different sites and seasons

\begin{tabular}{|c|c|c|c|c|c|c|c|c|c|c|c|c|c|c|}
\hline \multirow[t]{2}{*}{ Parameters } & \multicolumn{3}{|c|}{ Panchgram } & \multicolumn{3}{|c|}{ Annapurnaghat } & \multicolumn{3}{|c|}{ Sadarghat } & \multicolumn{3}{|c|}{ Katakhal } & \multirow{2}{*}{$\begin{array}{l}\text { ANOVA Season } \\
\text { effect ( } F \text { value) }\end{array}$} & \multirow{2}{*}{$\begin{array}{l}\text { ANOVA Site } \\
\text { effect (F value) }\end{array}$} \\
\hline & M & S & W & M & S & W & M & S & W & M & S & W & & \\
\hline $\mathrm{pH}$ & 6.25 & 6.45 & 6.23 & 6.83 & 6.75 & 6.94 & 6.37 & 6.26 & 6.48 & 6.76 & 6.46 & 6.67 & 0.653 (NS) & $11.01 * *$ \\
\hline $\mathrm{DO}(\mathrm{mg} / \mathrm{L})$ & 5.36 & 5.1 & 3.3 & 9.66 & 6.74 & 6.94 & 8.53 & 7.46 & 5.8 & 7.4 & 6.9 & 7.1 & $5.95 *$ & $9.33^{*}$ \\
\hline $\mathrm{FCO}_{2}(\mathrm{mg} / \mathrm{L})$ & 4.3 & 4.0 & 3.3 & 4.3 & 2.6 & 1.34 & 2.6 & 2.3 & 1.3 & 4.0 & 3.3 & 2.34 & $14.51 * *$ & $7.95^{*}$ \\
\hline $\begin{array}{l}\text { Alkalinity } \\
\text { (mg/L) }\end{array}$ & 14.0 & 16.66 & 18.0 & 7.0 & 10.6 & 15.6 & 10.0 & 16.3 & 16.6 & 11.0 & 16.0 & 18.3 & $26.45 *$ & $8.34 *$ \\
\hline
\end{tabular}

Letter in parentheses indicates season

$M$ monsoon, $S$ summer, $W$ winter. Average values are presented in $\mathrm{mg} / \mathrm{L}, N S$ not significant

* Indicates significant at $P<0.05$, ** indicates significant at $P<0.01$ 
Table 3 Bacterial quantity analysis of the water samples from different sites and seasons

\begin{tabular}{|c|c|c|c|c|c|c|c|c|c|c|c|c|c|c|}
\hline \multirow[t]{2}{*}{ Parameters } & \multicolumn{3}{|c|}{ Panchgram } & \multicolumn{3}{|c|}{ Sadarghat } & \multicolumn{3}{|c|}{ Annapurnaghat } & \multicolumn{3}{|c|}{ Katakhal } & \multirow{2}{*}{$\begin{array}{l}\text { ANOVA Season } \\
\text { effect ( } F \text { value) }\end{array}$} & \multirow{2}{*}{$\begin{array}{l}\text { ANOVA Site } \\
\text { effect (F value) }\end{array}$} \\
\hline & M & $S$ & W & M & $S$ & W & M & $S$ & W & M & $S$ & W & & \\
\hline $\mathrm{TC}\left(\times 10^{3}\right)$ & 49 & 42 & 22 & 13 & 11 & 12 & 40 & 38 & 26 & 21 & 21 & 8 & $6.40 *$ & $14.87 * *$ \\
\hline TFC (MPN/100 ml) & 1,600 & 280 & 175 & 910 & 210 & 140 & 1,600 & 350 & 280 & 910 & 280 & 110 & $23.64 * *$ & 0.79 (NS) \\
\hline $\operatorname{TVC}\left(\times 10^{3}\right)$ & 42 & 34 & 19 & 27 & 12 & 10 & 40 & 28 & 18 & 22 & 21 & 18 & $10.87 *$ & $6.07 *$ \\
\hline $\mathrm{SA} / \mathrm{SH}\left(\times 10^{3}\right)$ & 55 & 45 & 49 & 39 & 28 & 29 & 63 & 27 & 16 & 11 & 3 & 5 & $2.1(\mathrm{NS})$ & $136.29 * *$ \\
\hline Pseudomonas spp. $\left(\times 10^{3}\right)$ & 14 & 16 & 9 & 12 & 8 & 11 & 16 & 13 & 3 & 8 & 5 & 3 & 2.09 (NS) & $3.01(\mathrm{NS})$ \\
\hline
\end{tabular}

Letter in parentheses indicates season

$M$ monsoon, $S$ summer, $W$ winter, $N S$ not significant

Average values are presented in $\mathrm{mg} / \mathrm{L}$

* Indicates significant at $P<0.05$, ** Indicates significant at $P<0.01$

the highest population of TC followed by Annapurnaghat site during monsoon season. The high bacterial population at the Annapurnaghat site indicated mixing of some domestic wastes along with rain water in monsoon time. A similar pattern was obtained at the Sadarghat and Katakhal sites. Statistical analysis also showed significant variations between different sites and different seasons (ANOVA, $P<0.05$ and 0.01 ). The TC count was relatively higher in monsoon and summer seasons than winter. Similar observations were made in the Gangetic River by Sood et al. (2008). The highest coliform bacterial population in the monsoon season in the present study is similar with the reports of earlier studies (Badge and Varma 1982; Badge and Rangari 1999). The highest population of SA/SH was observed in the Panchgram site during the monsoon season followed by Annapurnaghat and Sadarghat whereas population of SA/SH in the Katakhal site was almost negligible. Therefore, significant variation was noted between different sites (ANOVA, $P<0.01$ ). But insignificant variations were observed between different seasons (ANOVA, $P<0.05$ and 0.01 ). Sewage contamination of river water particularly in the Panchgram site is detected by enumerating the coliform groups of bacteria (Fujioka 2002). Panchgram site near the Hindustan Paper Corporation and Annapurnaghat showed relatively high level of total coliform, total viable count, SA/SH and Pseudomonas spp. High values of bacterial populations near the Panchgram site might be due to discharge of high volumes of pulp paper mill wastes. This result coincides with observations of the Gola River by Chandra et al. (2006). It is universally accepted that, higher sewage contamination would lead to increased number of coliform and faecal coliform in natural water bodies. Hansen and Bech (1996) clearly suggest the proliferation of allochthonous microflora in the river environment. Further, as inestimable pathogenic bacteria will constitute the microflora of effluents discharged from different activities, quantifying different groups of pathogenic bacteria have to be part of such surveys. For instance, information on occurrence, abundance and distribution of potent human pathogens, Vibrio cholera (causing cholera in humans), Vibrio parahaemolyticus (gastroenteritis), Salmonella and Shigella sp. (typhoid fever, food poisoning), Streptococcus sp.(meningitis and skin infections) and Pseudomonas aeruginosa (pulmonary and lung infections) in aquatic environment may prove useful in public health management. The highest population of all the examined groups of bacteria was observed during the monsoon season. Kistemann et al. (2002) observed that in the case of rainfall, the microbial loads of running water may suddenly increase and reach reservoir bodies very quickly. Pathogenic bacteria which may cause serious problem for human health have been studied mostly for their survival in the aquatic ecosystem (Sood et al. 2008; Nagvenkar and Ramaiah 2009). The presence of Pseudomonas spp. in all the sites during all seasons may be attributed to human activities and sewage discharge to these sites.

The rising trend of total alkalinity during summer and winter seasons may be due to higher evaporation of water during low rainfall period which led to an increase in the concentration of carbonates and bicarbonates of calcium and magnesium. On the other hand, a decline in the alkalinity value from monsoon season was brought about by dilution due to heavy rainfall (Sahu 1991; Shinde et al. 2011). The $\mathrm{pH}$ values in all the sites were found to be high indicating the water bodies are not so acidic. Higher values of dissolved oxygen (DO) during the monsoon season may be due to heavy rainfall during this period led to increased aeration of river water (Sridhar et al. 2006; Adeyemo et al. 2008). Higher values of $\mathrm{CO}_{2}$ during monsoon season may be attributed to the heavy input of sewage and other organic and inorganic pollutants due to surface run off as a result of heavy showers during this period. These materials in course of time oxidised which led to their decomposition 
and consequent release of $\mathrm{CO}_{2}$ onto water, whereas lower values of $\mathrm{CO}_{2}$ were observed during the summer and winter seasons, which may be due to more transparency and more photosynthesis (Shinde et al. 2011). The effect of different seasons was statistically analysed within different physico-chemical parameters. The two-way ANOVA test revealed that there were significant variations noted (ANOVA, $P<0.05$ and 0.01) among different physicochemical parameters except $\mathrm{pH}$. Irregular pattern of $\mathrm{pH}$ values over the seasons as well as among the study sites may be due to high mixing rate of river water. Similar results were also observed in Narmada River (Gupta et al. 2000).

In this study, most of the sites were not suitable for domestic purpose with respect to the maximum permissible limits of total coliform and total faecal coliform as per the standards of National River Conservation Directorate, India. McLellan et al. (2001) stated that faecal pollution indicator organisms can be used to determine the number of cases related to the impacts on human health as well as health of aquatic ecosystems. The presence of such indicator organisms may provide information regarding waterborne diseases and is a direct threat to human, animal and aquatic organisms. The study clearly revealed that, the water becomes unfit for drinking as well as domestic purposes because of contamination due to industrial and domestic wastes. The present study also clearly stated that there is a significant presence of bacterial pollution indicators and pathogenic bacterial groups. The situation of the Barak River is not very serious but very alarming.

\section{Conclusions}

The observations clearly indicate that, all the studied sites of the Barak River have been contaminated with waterborne pathogenic bacteria. This may be due to increased anthropogenic and socio-cultural activities at different sites of the Barak River. Occurrence of pathogenic bacterial genera in the Barak River suggests that they may be explored as indicator organisms. Overall bacteriological analysis of the Barak River water revealed that the river water was polluted by sewage, faecal contaminants and industrial wastes and the water of the Barak River is not suitable for drinking and other recreational purposes. Regular monitoring of microbial contamination in the water of Barak River should be an essential component for the protection strategy of the public health.

Acknowledgments The authors are grateful to the Head, Department of Life Science and Bioinformatics, Assam University, Silchar for providing laboratory facilities. The financial support of University Grant Commission (UGC) is also highly acknowledged.
Open Access This article is distributed under the terms of the Creative Commons Attribution License which permits any use, distribution, and reproduction in any medium, provided the original author(s) and the source are credited.

\section{References}

Adeyemo OK, Adedokum OA, Yusuf RK, Adeleye EA (2008) Seasonal changes in physico-chemical parameters and nutrient load of river sediments in Ibadan city, Nigeria. Glob NEST 10:326-336

APHA (1998) Standard methods for the examination of water and wastewater, 20th edn. USA, Washington DC

Arvanitidou M, Kanellou K, Vagiona DG (2005) Diversity of Salmonella spp. and fungi in northern Greek rivers and the correlation to faecal pollution indicators. Environ Res 99:278-284

Badge US, Rangari AK (1999) Periodicity of coliforms bacteria in an aquatic environment. Water Sci Technol 40:151-157

Badge US, Varma AK (1982) Distribution and periodicity of total, faecal coliform bacteria in an aquatic ecosystem. Int $\mathrm{J}$ Environ Stud 19:215-220

Badra B, Mukherjee S, Chakraborty R, Nanda AK (2003) Physicochemical and bacteriological investigation on the river Torsa of North Bengal. J Environ Biol 24:125-133

Chandra R, Singh S, Raj A (2006) Seasonal bacteriological analysis of Gola River water contaminated with pulp paper mill waste in Uttaranchal, India. Environ Monit Assess 118:393-406

Fujioka R (2002) Microbial indicators of marine recreational water quality. In: Hurst CJ, Crawford RL, Knudsen G, McIneney MJ, Stetzenbach LD (eds) Manual of environmental microbiology. American Society for Microbiology Press, Washington DC

Gupta KM, Shrivastava P, Singhal KP (2000) Pollution status of River Narmada between Mandla and Bhedaghat. Environmental Pollution and its Management. APH Pubi.crop

Hansen B, Bech G (1996) Bacteria associated with a marine planktonic copepod in culture. I. Bacterial genera in seawater, body surface, intestines and faecal pellets and succession during faecal pellet degradation. J Plankton Res 18:257-273

ISI (1991) Indian Standard specification for drinking water. (BIS 10500: 1991) ISI, India

Kistemann T, Claben T, Koch C, Dangendorf F, Fischeder R, Gebel J, Vacata V, Exner M (2002) Microbial load of drinking water reservoir Tributaries during extreme rainfall and runoff. Appl Environ Microbiol 68:2188-2197

Koshy M, Nayar TV (1999) Water quality aspects of river Pamba. Pollut Res 18:501-510

McLellan SL, Daniels AD, Salmore AK (2001) Clonal population of thermotolerant enterobacterioaceae in recreational water and their potential interference with faecal Escherichia coli counts. Appl Environ Microbiol 67:4934-4938

Nagvenkar GS, Ramaiah N (2009) Abundance of sewage-pollution indicator and human pathogenic bacteria in a tropical estuarine complex. Environ Monit Assess 155:245-256

Sahu BK (1991) A study of the aquatic pollution load in the River Brahamin, Ph.D thesis, Sambalpur University

Scott TM, Salina P, Portier KM, Rose JB, Tamplin ML, Farrah SR, Koo A, Lukasik J (2003) Geographical variation in ribotype profiles of Escherichia coli isolates from human, swin, poultry, beef and dairy cattle in Florida. Appl Environ Microbiol 69:1089-1092

Shinde SE, Pathan TS, Raut KS, Sonawan DL (2011) Studies on the physico-chemical parameters and correlation coefficient of

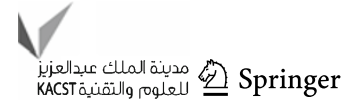


Harsool savani Dam, District Aurangabad, India. Middle-East J Sci Res 8:544-554

Sood A, Singh KD, Pandey P, Sharma S (2008) Assessment of bacterial indicators and physicochemical parameters to investigate pollution status of Gangetic river system of Uttarakhand (India). Ecol Indic 8:709-717

Sridhar R, Thangaradjou T, Senthil Kumar S, Kannan L (2006) Water quality and phytoplankton characteristics in the Palk Bay, southeast coast of India. J Environ Biol 27:561-566
Steel RG, Torrie JH (1992) Principles and procedures of statistics. McGraw Hill Book Co. Inc., New York

World Health Organisation (1996) Guidelines for drinking water quality, vol 2. WHO, Geneva 